Book Review

\title{
Mouffe, Chantal, For a Left Populism ${ }^{1}$
}

Jovito V. Cariño

$\mathrm{M}$ y main interest on populism stems largely from my desire to make sense of the Philippines's homegrown populism, specifically, its origins and the potential responses with which such phenomenon may be addressed. My foray into this topic began with Jan-Werner Müller's What is Populism? (2017) which I reviewed for Kritike in the previous issue. ${ }^{2}$ Müller's book is important in the way it provides a comprehensive account of populism both as a historical episode and as a sociopolitical fact. Readers looking for an introductory material on populism will surely find in Müller's work an excellent resource due not only to the wealth of information it offers but also to the engaging narrative with which such pieces of information were woven. Despite its merits however, What is Populism? is simply not the type of material that one goes to for alternative perspectives on populism within the context of the contemporary political discourse. My turn, then, to Chantal Mouffe's For a Left Populism (2018) was motivated by my aim to find this missing link and enrich my understanding of this phenomenon with a recourse to political theory. Mouffe's name, of course, became a byword among scholars of radical democracy first as a conduit of Ernesto Laclau (Hegemony and Socialist Strategy, 1985) before she found her own voice and built a reputation on her own via her recent and previous works most notably Agonistics: Thinking The World Politically (2013), On The Political (2005), The Democratic Paradox (2000), and The Return of the Political (1993). To date, Mouffe is widely acknowledged as one of the leading theorists of democracy or more precisely, one of the staunchest and most vocal advocates of leftist politics. Mouffe's take on populism, unlike that of Müller, is presented against a more restricted background, that is, the political landscape of Western Europe, or to be more specific, the post-Cold War Great Britain, stretching from Margaret Thatcher to Tony Blair down to the contemporary rising star of British politics, Jeremy Corbyn. The centrality of British political scene in Mouffe's For A Left Populism is not a surprise for anyone who has

\footnotetext{
${ }^{1}$ London: Verso, 2018, 98pp.

${ }^{2}$ See Jovito V. Cariño, Review of What is Populism? by Jan-Werner Müller, Kritike: An Online Journal of Philosophy, 13:1 (June 2019), 161-163.
}

(C) 2019 Jovito V. Cariño

https://www.kritike.org/journal/issue 25/carino december2019.pdf

ISSN 1908-7330

(c) BY-NC-ND 


\section{FOR A LEFT POPULISM}

followed Mouffe's intellectual career. Great Britain after all is where Mouffe has spent most of her time the last thirty years, teaching and writing as a political theorist at the University of Westminster although she was by birth a Belgian national. Mouffe considered populism as a manifestation of the widespread discontent over the failures and undelivered promises of liberal economy. The earlier gains by the liberal order, forged by the ingenious attempt of the conservatives to marry labor with capital, led to the subordination of democratic politics in favor of an efficient system for the creation and management of wealth. The initial success of this new hegemony, described by Mouffe as "post-democracy," contributed to the spread of popular myth that liberal democracy cannot exist independently of financial capitalism. ${ }^{3}$ When this hegemonic order began showing cracks in the early 1990s before climaxing to the collapse of US financial system in 2008, one of the most immediate reactions came in the form of a consensus between the right and the left which paved the way not just for the blurring of the ideological divide between the two but also for the intensification of financial institutions' encroachment into the dynamics of democratic politics. The preservation of this new hegemonic arrangement became the prime advocacy of the social democrats and is at the heart of what Mouffe described as "postpolitics." 4 One of the core insights propounded by Mouffe in this book is her straightforward refutation of the post-democratic and the post-political fiction identifying liberal democracy with liberal economy and her calling out of Marxism for peddling the same blunder. Mouffe pointed out that "there is no necessary relationship between capitalism and liberal democracy. It is unfortunate that Marxism has contributed to this conclusion by presenting liberal democracy as the superstructure of capitalism." ${ }^{5}$ Mouffe believed there is always a way to contest the excesses of capitalist hegemony without abandoning the project of democratic politics, in particular, the two ethical principles which fuel democratic politics forward, to wit, liberty and equality. ${ }^{6}$ The retrieval of these principles and their reinstatement within what Mouffe termed a "chain of equivalence," a recreated social relations built on a notion of radical democratic citizenship ${ }^{7}$ are at the core of Mouffe's articulation of a left populism. If one sums up Mouffe's idea of a left populism, it would amount to an attempt to radicalize democracy via a reconstitution of political subjectivity (Ernesto Laclau's creation of "people") and the enlargement of spaces that would make room for agonistic forms of political action towards the retrieval and inscription of the ethical principles

\footnotetext{
${ }^{3}$ Ibid., 12-13.

${ }^{4}$ Ibid., 17.

${ }^{5}$ Ibid., 48.

${ }^{6}$ See Ibid., 40-46.

${ }^{7}$ Ibid., 66.
}

(c) 2019 Jovito V. Cariño

https://www.kritike.org/journal/issue 25/carino december2019.pdf

ISSN 1908-7330

(c) BY-NC-ND 
of liberty and equality into the democratic imaginary. In brief, it is an alternative to a populism propagated by the right with its flirtations with authoritarianism and wholesale subscription to neoliberal economic hegemony while maintaining a token adherence to a residual democracy. Mouffe punctuated her point with a quote from the eminent Marxist scholar David Harvey: "It is the profoundly anti-democractic nature of neoliberalism backed by the authoritarianism of the neo-conservatives that should surely be the focus of the social struggle." ${ }^{8}$ The preceding sentence may not have the word "Philippines" in it but it sure reads like Rodrigo Duterte's Philippines to me. For a Left Populism might have been written by Mouffe with the British politics as a background and a perspective that was patently Western European but its emphatic message on the cause of radical democracy surely has global resonance. That a left populism is possible, that is, that democracy can be recovered from the neoliberal hegemony, should be a welcome news for anyone who believes in the resurgent potential of the political.

Department of Philosophy, University of Santo Tomas, Philippines

\section{References}

Cariño, Jovito V., Review of What is Populism? by Jan-Werner Müller, Kritike: An Online Journal of Philosophy, 13:1 (June 2019).

Harvey, David, Brief History of Neoliberalism (New York: Oxford University Press, 2005).

Mouffe, Chantal, For a Left Populism (London: Verso, 2018).

${ }^{8}$ David Harvey, A Brief History of Neoliberalism (New York: Oxford University Press, 2005), as quoted in Mouffe, For a Left Populism, 50. 